\title{
過剰 $\mathrm{Si}$ 添加 Al-Mg-Si 合金薄板材の静的引張特性に及ぼす 試験片寸法と形状の影響
}

\author{
木下 勝之 * ·大㠃 修平 *
}

Journal of Japan Institute of Light Metals, Vol. 56, No. 5 (2006), pp. 249-254

\section{Effect of specimen size and shape on static tensile properties of Si-rich Al-Mg-Si alloy sheets}

\begin{abstract}
Katsuyuki KINOSHITA* and Shuhei OSAKI*
Effects of specimen size and shape, grain size and aging condition on static tensile properties of Si-rich 6000 aluminum alloy sheets were investigated. The static tensile tests were carried out by using specimens both under-aged and peakaged having six kinds of different size including standardized one of JIS 13B, two (coarse and fine) grain sizes. With the decrease in specimen size, yield strength decreased, while elongation increased. This response was remarkable in the case of the alloy with coarse grain size. From the SEM observation on fracture surface, the change in the elongation with decreasing specimen size was attributed to the shift of fracture mode from integranular to transgranular. The dependence of specimen size and shape was able to be explained with a parameter of the ratio of specimen width to grain size.
\end{abstract}

(Received April 202005 Accepted November 28, 2005)

Keywords: Al-Mg-Si alloys, specimen size, tensile properties, fracture mode

\section{1. 緒言}

近年，環境問題への対応から自動車のより一層の軽量化が 求められている。そこで, 軽量でかつベークハード特性をも ち，さらに耐食性に優れている 6000 系アルミニウム合金 ${ }^{1)}$ が注目されている。自動車のパネル材に 6000 系アルミニウム 合金を適用するためには, シート材の動的な機械的特性を把 握しておく必要がある。シート材の動的特性を試験する方法 のひとつとして，ホプキンソン棒法衝撃試験が挙げられる。 この試験は, 最も信頼性の高い衝撃試験法として知られてい るが，試験片サイズに制約のある問題点がある。以前からホ プキンソン棒法における試験片サイズの影響について指摘さ れ, 丸棒試験片について，いくつか研究 ${ }^{2), 3)}$ がなされてい

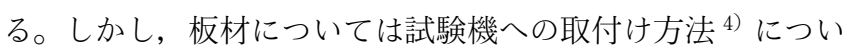
て検討されているのみで，適切な試験片のサイズや形状につ いて十分に明らかにされているわけではない。

著者らは，これまで強度・成形性改善を目指した過剩 Si 添 加や $\mathrm{Cu}$ 添加した 6000 系合金について静・動的引張試験を行 い，特に静的特性において著しい試験片サイズ効果が現れる ことを示してきた ${ }^{5)}$ 。すなわち, その静的試験では, 過剰 $\mathrm{Si}$ 添加材および $\mathrm{Cu}$ 添加材ともに破断伸びが，試験片サイズが 小さくなると 2 6 倍も増加する挙動が見られ，また，耐力は 亜時効材およびピーク時効材では低下する一方, 過時効材で は増大した。しかし，この試験では，同一合金で 2 種類のみ の試験片サイズであったため, 試験片サイズ効果を十分解明 するには至らなかった。
そこで本研究では, 過去の実験で特に試験片サイズの影響 が大きく現れた過剰 Si 合金のシート材について, 試験片サイ ズを広範に変化させて静的引張試験を行った。合せて, Cr 添 加による結晶粒微細化合金についても同様に試験し，静的引 張特性に及ぼす試験片サイズ，結晶粒サイズおよび時効条件 の影響を明らかにし，これらの諸因子間の関係について検討 した。

\section{2. 実験方法}

\section{1 供試材}

供試材は(社)軽金属学会の研究部会「粒界近傍の材料物性 部会」の共通試験片として提供された $\mathrm{Al}-\mathrm{Mg}-\mathrm{Si}$ 系合金で, Table 1 にその化学組成を示す。 $\mathrm{Mg}$ 含有量を $0.7 \mathrm{mass} \%$ 一定 として, 過剩 $\mathrm{Si}$ を添加した合金 No. 4 とさらに Cr 添加した 合金 No. C4の 2 種類を用いた。均質化処理, 熱間圧延の後, 冷間圧延により製造された板厚 $1 \mathrm{~mm}$ のシート材である。熱 処理は $813 \mathrm{~K}-3.6 \mathrm{ks}$ の溶体化後水焼入れを行い， $448 \mathrm{~K}$ の油浴 中で時効処理を行った。時効時間は，硬さ試験により $3.6 \mathrm{ks}$

Table 1 Chemical composition of the alloys in mass \% and grain size, $d$, of the alloy sheets

\begin{tabular}{l|c|c|c|c|c|c|c|c}
\hline \hline Alloy & $\mathrm{Si}$ & $\mathrm{Fe}$ & $\mathrm{Cu}$ & $\mathrm{Mg}$ & $\mathrm{Mn}$ & $\mathrm{Zn}$ & $\mathrm{Cr}$ & $d$ \\
\hline No. 4 & 0.76 & 0.03 & 0.01 & 0.71 & 0.01 & 0.01 & 0.00 & $139 \mu \mathrm{m}$ \\
No. C4 & 0.76 & 0.20 & 0.01 & 0.73 & 0.01 & 0.01 & 0.21 & $31 \mu \mathrm{m}$ \\
\hline
\end{tabular}

*山口大学工学部機械工学科（７ 755-8611 山口県宇部市常盤台 2-16-1）。Faculty of Engineering, Yamaguchi University（2-16-1 Tokiwadai,

Ube-shi, Yamaguchi 755-8611).E-mail: kinosita@yamaguchi-u.ac.jp 
Table 2 Dimension of the tensile specimens

\begin{tabular}{c|c|c|c|c}
\hline \hline & $\begin{array}{c}\text { Width } \\
W \\
(\mathrm{~mm})\end{array}$ & $\begin{array}{c}\text { Length of } \\
\text { reduced } \\
\text { section } \\
L(\mathrm{~mm})\end{array}$ & $\begin{array}{c}\text { Radius } \\
\text { of fillet } \\
R(\mathrm{~mm})\end{array}$ & $\begin{array}{c}\text { Width/ } \\
\text { Thickness } \\
W / T\end{array}$ \\
\hline S1 & 2 & 4 & 1 & 2 \\
S2 & 3 & 4 & 1 & 3 \\
S3 & 6 & 16 & 4 & 6 \\
S4 & 8 & 16 & 4 & 8 \\
S5 & 8 & 30 & 10 & 8 \\
S6 & 12.5 & 60 & 20 & 12.5 \\
\hline
\end{tabular}

(a)

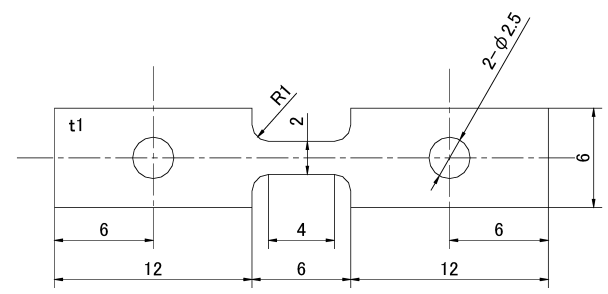

(b)

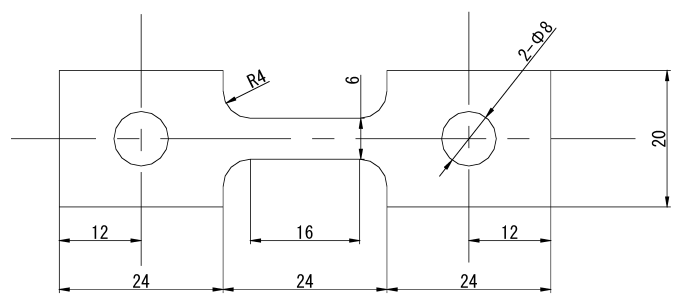

(c)

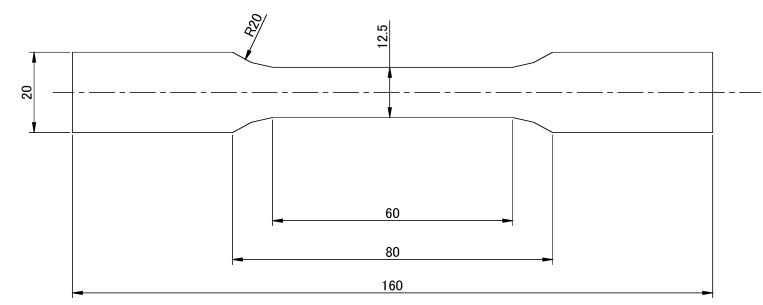

Fig. 1 Shape and dimension of tensile specimens.

のものを亜時効（UA），最高硬さが得られた $28.8 \mathrm{ks}$ をピーク 時効（PA）とした。なお結晶粒の形状は, 圧延面ではほぼ等 軸であり，その平均結晶粒径は合金 No. 4, No.C4でそれぞれ 約 $140,30 \mu \mathrm{m}$ であった。

\section{2 引張試験}

引張特性に及ぼす試験片サイズの影響を調べるため, Table 2 に示すような試験片平行部の幅 $(W)$ と長さ $(L)$ を変化させた 6 種類の試験片を作製した。Fig. 1 に例として, 肩部の半径 $(R)$ とつかみ部の形状が異なる $\mathrm{S} 1, \mathrm{~S} 3, \mathrm{~S} 6$ サイ ズの試験片の形状を示す。なお， $\mathrm{S} 1$ S5 は, つかみ部にピン 穴をむつ形状とし，S6 は，JIS に規定された厚さ $3 \mathrm{~mm}$ 以下の 定形試験片 $13 \mathrm{~B}$ 号である。平行部断面のアスペクト比 $W / T$

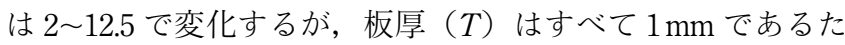
め $W$ と同一数值となる。引張試験は, インストロン型引張 試験機を用いて常温空気中にてひずみ速度 $5 \times 10^{-5} / \mathrm{s}$ で行い, それぞれの試験片について S6 を除き 2 回ずつ行った。試験
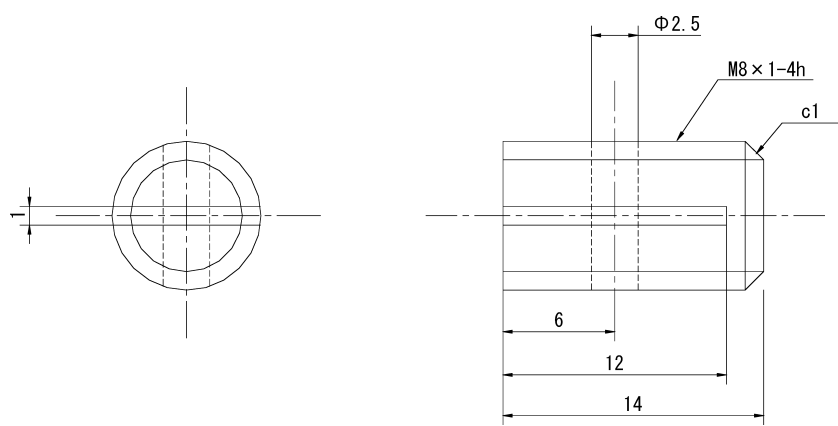

Fig. 2 Shape and dimensions of specimen fastener.

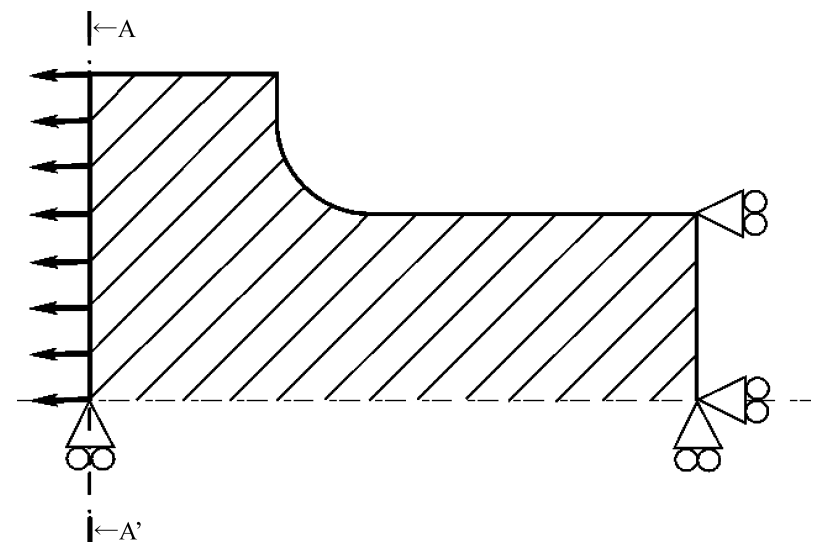

Fig. 3 Boundary condition for FEM analysis.

片の取付けは, S1 から S5 では試験機のチャックにピンで固 定する方式としたが，S1 と S2 については，Fig. 2 に示す治 具を介して取付ける方式を採った。S6については, 荷重值が 大きくなるため端部を直接つかむ方式とした。

\section{FEM 解析}

引張特性に影響を与える要因としては, 試験片の幾何学的 な形状のみならずミクロ組織的因子と形状との相互効果が考 えられる。そこで, 試験片の形状因子のみの影響を検討する ために FEM 解析を行った。すなわち, 真応力 - 真ひずみの 構成関係としてはサイズの最も大きな試験片 S6（合金 No. 4-UA 材) のそれを基に, Fig. 3 に示す各試験片の 1/8 モデル

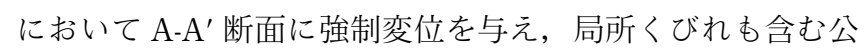
称ひずみ $25 \%$ を終了条件として公称応力ー公称ひずみ応答 を算出した。試験片の形状因子がこの応答, 特に耐力 $\left(\sigma_{0.2}\right)$ や破断伸び $(\delta)$, 均一伸び $\left(\delta_{\mathrm{U}}\right)$ にいかに影響を与えるかを 推定した。さらに相当塑性ひずみ分布を観察することによっ て， $\delta_{\mathrm{U}}$ にどのような影響を与えるか調べる。局部伸び $\left(\delta_{\mathrm{L}}\right)$ に関しては, 局部くびれ領域の広がりが要素サイズに依存 し6), 試験片サイズの違いに対して相対的な比較ができない ため検討しない。なお, 本解析は, 汎用ソフトANSYSを用 いて大変形を考慮した 3 次元静的弾塑性解析とし, 材料定数 はヤング率とポアソン比をそれぞれ $70 \mathrm{GPa}, 0.33$ と与えた。

\section{4. 実験 結果}

試験片サイズ，結晶粒サイズおよび時効条件を変えた全試 験片の $\sigma_{0.2}$ および $\delta$ を Fig. 4 と Fig. 5 にそれぞれ示す。な お, Fig. 5 の棒グラフのブランク部長さは $\delta_{\mathrm{U}}$ を表す。まず, 


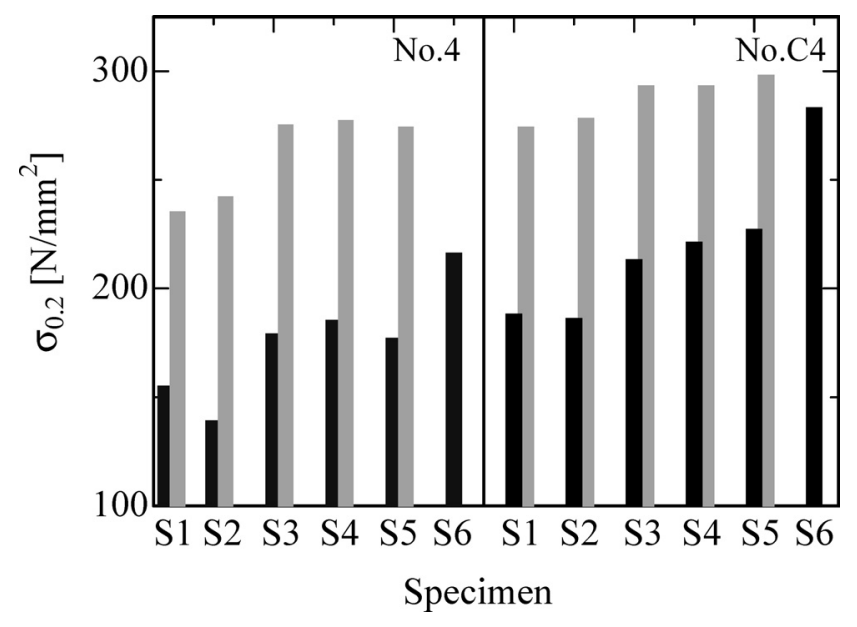

Fig. $40.2 \%$ proof stress, $\sigma_{0.2}$, of the specimens (UA: PA: $\square$ ).

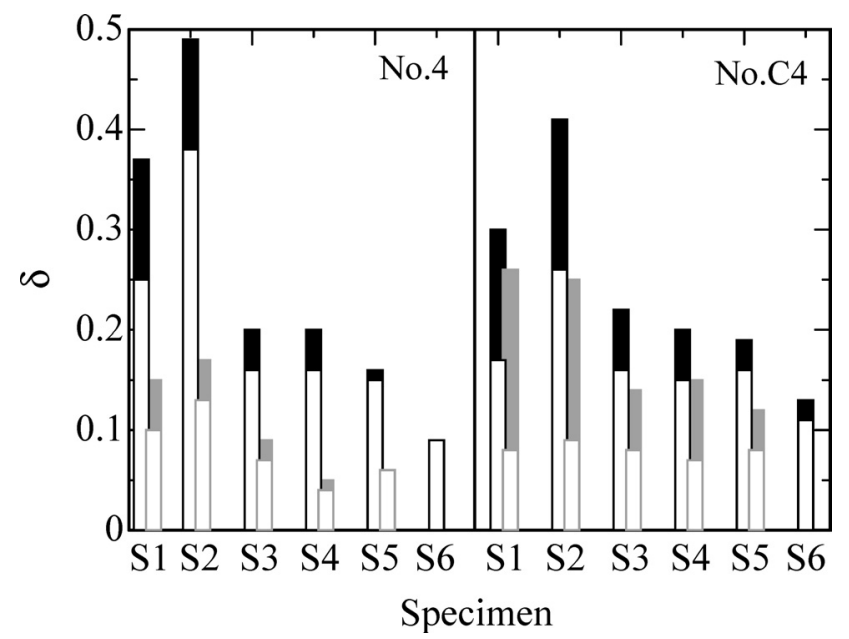

Fig. 5 Elongation, $\delta$, of the specimens (UA: $\mathbf{0}, \mathrm{PA}: \square$, uniform elongation: $\square$ ).

合金 No. 4 の UA 材に注目すると， $\sigma_{0.2}$ は S2 を除くと試験片 サイズが小さくなるに従い減少しており, S1の $\sigma_{0.2}$ はS 6 の 約 $70 \%$ となった。 $\delta$ は，S2 を除くと試験片サイズが小さく なるに従い, 増加する傾向が見られ, S1 は S6 より 4 倍近く も大きい值となった。 $\delta$ の内訳をみると, 試験片サイズが小 さいほど $\delta_{\mathrm{L}}$ の増大が顕著であった。すなわち, $\mathrm{S} 6$ で $\delta_{\mathrm{L}}$ がほ とんど認められないのに対して, S 1 では $\delta$ の約 $1 / 3$ を占めて いた。一般的にシート材では, 平行部断面のアスペクト比 $W / T$ が小さいほど $\delta_{\mathrm{L}}$ が増大するとされているが ${ }^{7)}$, 実際に その傾向が認められた。しかし， $\delta_{\mathrm{U}}$ 屯アスペクト比 $W / T$ に よって 2.7 倍も変化しており, 通常と異なる挙動も見られた。 No. 4 の PA 材についても $\sigma_{0.2}$ や $\delta$ の試験片サイズ依存性は UA 材とほぼ同じ傾向が見られた。次に合金No. C4のUA 材 についてみると, 試験片サイズが小さいほど $\sigma_{0.2}$ は減少, $\delta$ はS2 を除いて増加し, 合金 No. 4 と同じ挙動が見られた。し かし，その変化率は合金 No. 4 ほど大きくなかった。 $\delta_{\mathrm{U}}$ は, ほぼ一定で小試験片ほど $\delta_{\mathrm{L}}$ が増大したことがわかる。PA 材 についても試験片サイズ依存性は UA 材と類似の傾向であっ たが， $\sigma_{0.2}$ と $\delta$ の变化率は UA 材ほど顕著でなかった。以上 のように, 試験片 S2 を除いて試験片サイズが小さくなるに 従い, 合金 No. 4, No. C4 および時効条件 UA, PA によらず $\sigma_{0.2}$

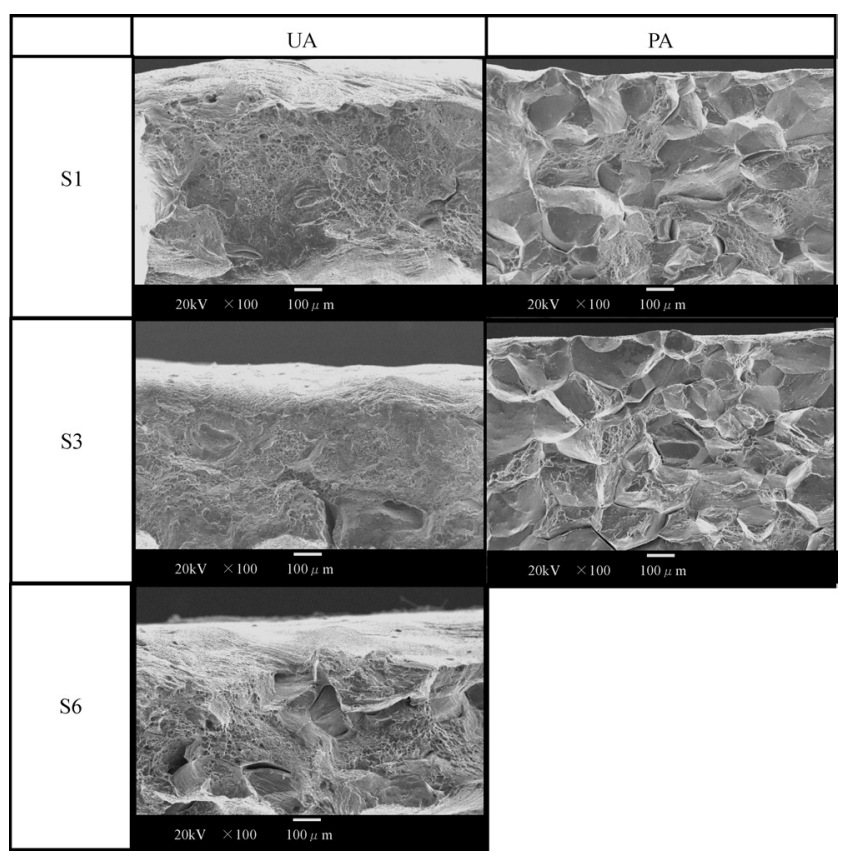

Fig. 6 SEM micrographs showing fracture appearance of the tensile specimens of alloy No. 4.

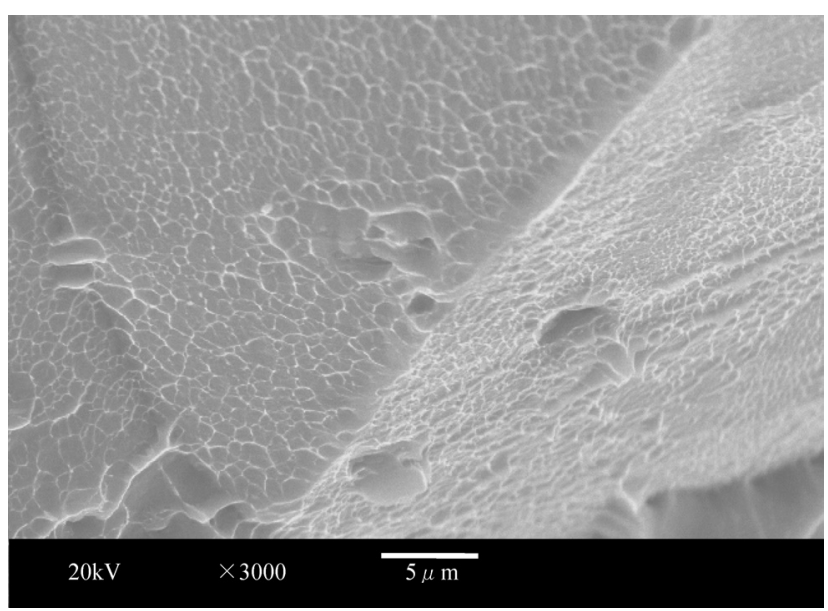

Fig. 7 Magnified SEM image of No. 4-S1-PA showing intergranular ductile fracture.

は減少し, $\delta$ は増加することがわかった。特に, 合金 No. 4 で は， $\delta_{\mathrm{U}}, \delta_{\mathrm{L}}$ ともに試験片サイズの減少に従い増大していた。 試験片 S2 はこの傾向から外れる特異な特性を生じた。

Fig. 6 に合金 No. 4 の試験片 S1, S3 および S6 における破 面 SEM 像を示す。UA 材の場合, S6 では粒界破壊と粒内破 壊の混合型であるのに対して, S1 では全面が粒内破壊を呈し ていた。S3でも S6 ほどではないが，一部粒界破壊を生じて いた。S6での粒界破壊は, Fig. 7 の拡大像に示すように粒界 面に微細なディンプルを伴う, いわゆる粒界延性破壊である ことがわかる。PA 材の場合, S1, S3 とも粒界破壊と粒内破 壊の混合型であるが, S1 より S3 で粒界破壊の割合が大であ ることが認められた。合金 No. C4 では, 破面 SEM 像は示さ ないが UA 材, PA 材ともに試験片サイズによらず粒内破壊を 呈していた。 


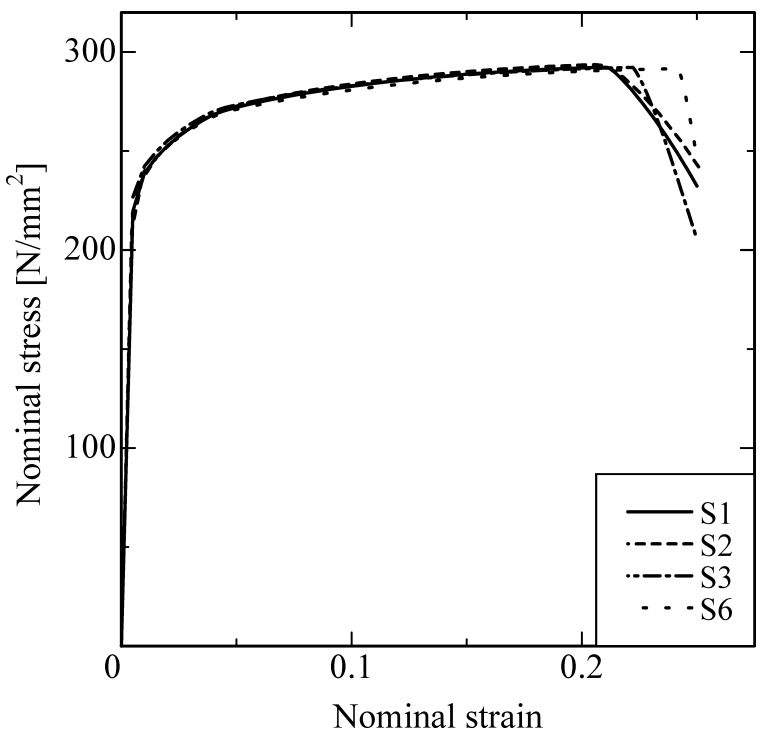

Fig. 8 Nominal stress vs. nominal strain relations obtained by the FEM analysis.

\section{5. 考察}

\section{1 幾何学的形状の影響}

以上のような $\sigma_{0.2}$ と $\delta$ に及ぼす試験片サイズ効果をまず平 行部断面のアスペクト比 $W / T$ や肩部半径 $R$ などの幾何学的 形状の要因から検討する。Fig. 8 に FEM 解析結果より得ら れた公称応力ー公称ひずみ線図を示す。本図は，3 章で述べた とおり, 試験片 S6（No.4-UA 材）の真応力 - 真ひずみ関係に 基づき Fig. 3 における A-A' 断面の反力と变位から求められる 荷重と伸びを試験片平行部の断面積と長さでそれぞれ除して 算出したあのである。解析結果の公称応力 - 公称ひずみ曲線 から求まる $\sigma_{0.2}$ は, 試験片平行部の幅方向に分布する応力の 平均值である。例えば $R$ の違いによって試験片平行部に応力 不均一が生じると異なる值になることが予想される。しかし， $\sigma_{0.2}$ は, 本解析では試験片形状に依存せずほとんど一定で あった。すなわち， $\sigma_{0.2}$ 自体は試験片形状に影響されないこ とがわかった。次に, $\delta_{\mathrm{U}}$ に注目すると, 解析では $\mathrm{S} 6>\mathrm{S} 3>\mathrm{S} 1=\mathrm{S} 2$ の順に大となり，実測と異なる結果となった。 $\delta_{\mathrm{U}}$ は, 平行部の長さ方向のひずみ総量として与えられるので 平行部全長にわたるひずみ分布を調べた。Fig. 9 に例として 公称ひずみ $5 \%$ における相当塑性ひずみ $\left(\bar{\varepsilon}^{\mathrm{P}}\right)$ 分布を示す。 $\bar{\varepsilon}^{\mathrm{P}}$ の最大值は当然平行部中央に生じるが, $\mathrm{S} 6$ が 0.0852, S1 が 0.0942 となった。つまり, 公称ひずみは同じでもサイズの 小さい S1 の方が, 平行部中央の塑性ひずみが大で, 塑性変 形がそれだけ進行することがわかる。

$\mathrm{S} 2$ では, 試験片平行部の中央付近における $\bar{\varepsilon}^{\mathrm{P}}$ の分布が不 均一な上に, 板幅のより小さい $\mathrm{S} 1$ よりも最大值が大きくなっ ていた。 S1 はS2 より小サイズであっても, 平行部の均一な ひずみ分布が維持されていた。S2におけるひずみの不均一分 布の原因としては, 試験片肩部が切欠きとして作用したこと が考えられる。各試験片について，両側に円弧状のフィレッ 卜を有する帯板の引張負荷における応力集中係数 $\alpha^{8)}$ は Table 3 として与えられる。本表には試験片平行部の幅 $W$ と 長さ $L$ の比を合せて示す。 $\alpha$ は $W / L$ が最大となる $\mathrm{S} 2$ で最大 であることがわかる。このことからあ, S2 では平行部長さに

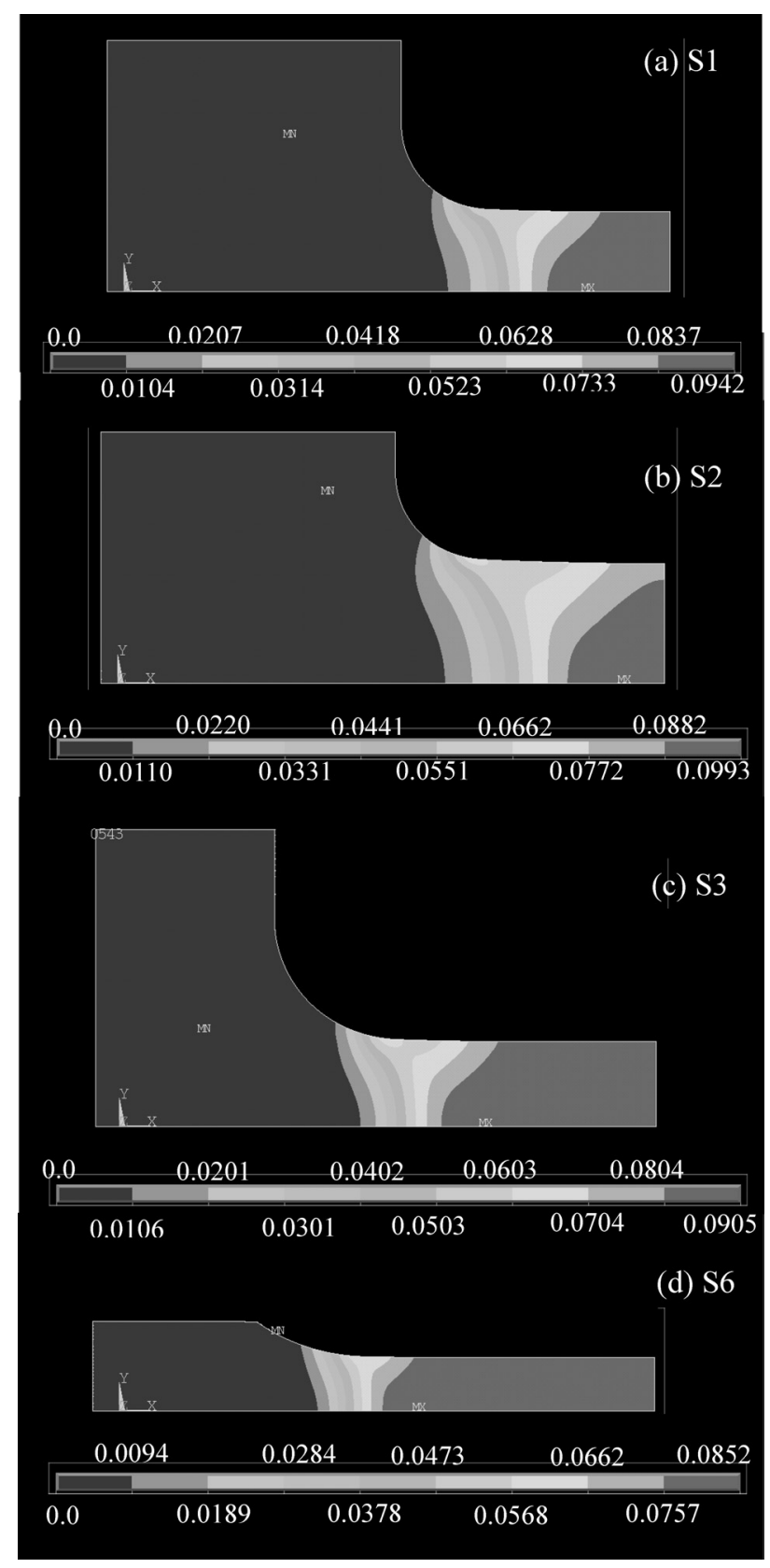

Fig. 9 Distribution of effective plastic strain obtained by the FEM analysis.

Table 3 Stress concentration factor, $\alpha$, and ratio $W / L$

\begin{tabular}{c|c|c|c|c|c|c}
\hline \hline Specimen & S1 & S2 & S3 & S4 & S5 & S6 \\
\hline$\alpha$ & 1.47 & 1.57 & 1.39 & 1.46 & 1.25 & 1.19 \\
$W / L$ & 0.50 & 0.75 & 0.38 & 0.50 & 0.27 & 0.21 \\
\hline
\end{tabular}

対して幅を大きくし過ぎたために, フィレットが応力集中要 素として働き, ひずみの不均一分布を招いたと言える。した がって, 試験片を設計する際には, 試験片フィレット底での $\alpha$ ととあに $W / L$ のバランスを取ることに注意すべきである。

FEM 解析による $\sigma_{0.2}$ および $\delta_{\mathrm{U}}$ の推定結果は, 実測と異な る試験片サイズ依存性となった。このことは引張特性が単に 試験片の幾何学的形状に依存するわけではないことを示して いる。S2については, 試験片平行部の中央まで幅方向の変形 


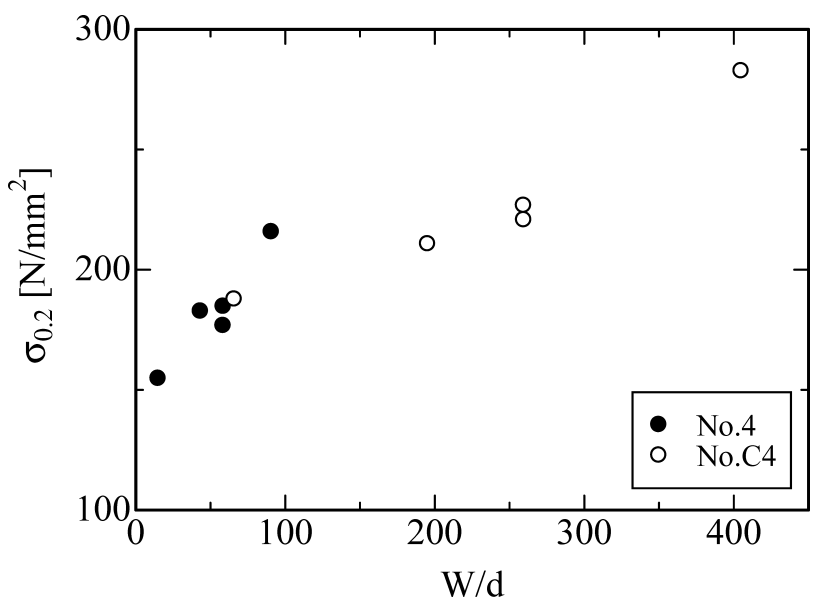

Fig. 10 Effect of $W / d$ on the $0.2 \%$ proof stress of underaged specimens.

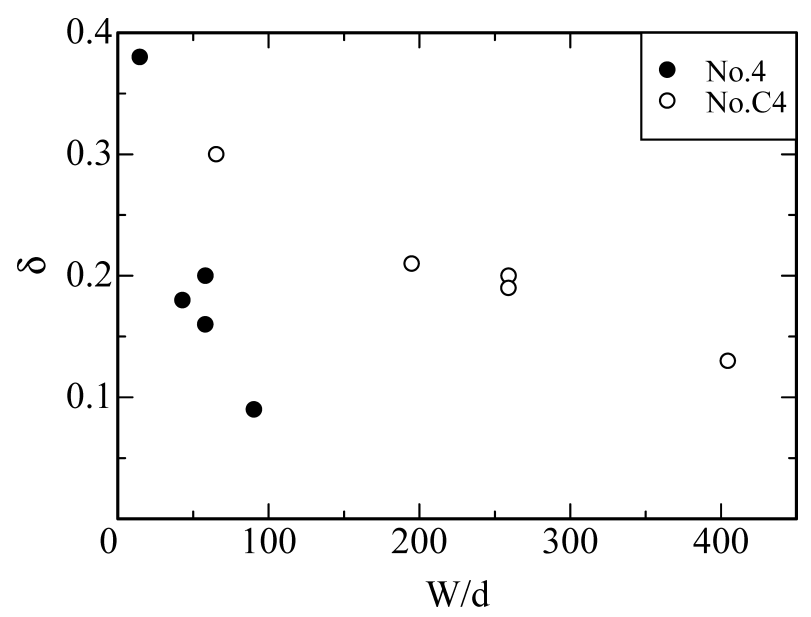

Fig. 11 Effect of $W / d$ on the elongation of under-aged specimens.

不均一が生じたことから不適切な試験片とし, 以下の議論に は含めないものとする。

\section{2 試験片形状とミクロ組織因子の相互効果の影響}

FEM 解析から $\sigma_{0.2}$ や $\delta$ のサズ依存性は, 幾何学的形状の みで説明できないことがわかった。他方，試験片の破壊形態 は，粗粒合金では試験片サイズによって粒界性から粒内性へ 遷移し，微粒合金では常に粒内性であるなどの挙動が見られ た。そこで, ミクロ組織因子として結晶粒径 $(d)$ と試験片 平行部の幅 $W$ の比 $W / d$ を用いて結果を整理する。Fig. 10 に $\sigma_{0.2}$ と W/d の関係を示す。合金 No. 4 に注目するとW/d の減 少とともに $\sigma_{0.2}$ は低下することがわかる。合金 No.C4 につい ても合金 No. 4 に比べて変化率は小さいが, W/d の減少とと あに低下している。これは, W/d が小さくなると試験片自由 表面に接する結晶粒数の割合が増え，いわゆる結晶粒間拘束 力 ${ }^{9)}$ が低下することで粒内すべりが容易になった結果と考え られる。

次いで, Fig. 11 に合金 No. 4 およびNo.C4のUA材におけ るW/d と $\delta$ の関係を示す。合金 No. 4 と合金 No. C4 ともに $W / d$ の減少に伴い $\delta$ は増加するが, 前者はその变化が顕著で あった。さらに $\delta$ の内訳を見るために Fig. 12 (a), (b) にそ れぞれ合金 No. 4 と No. C4 の $\delta, \delta_{\mathrm{U}}, \delta_{\mathrm{L}}$ と W/d の関係を示す。 合金 No. 4 では, $W / d$ の減少とともに $\delta_{\mathrm{U}}$ は単調に増加する傾
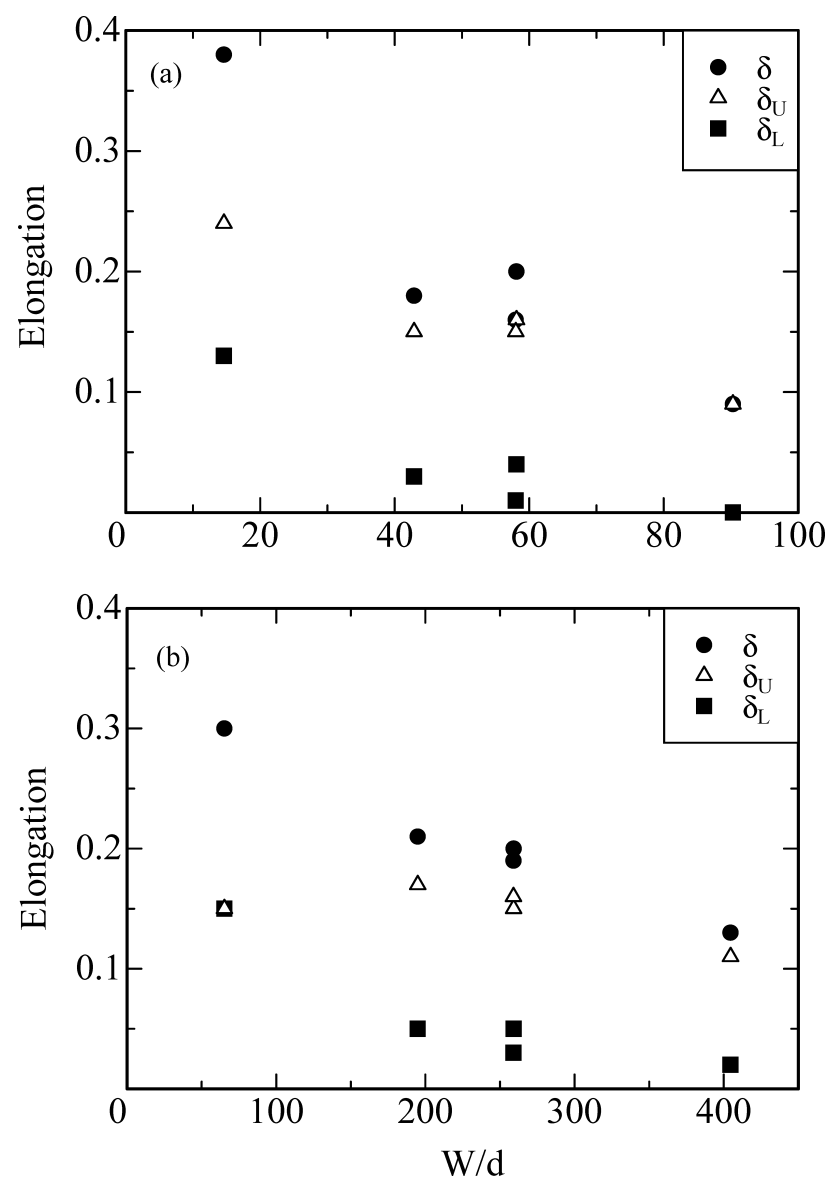

Fig. 12 Effect of $W / d$ on the uniform and local elongation ( $\delta_{\mathrm{U}}$ and $\delta_{\mathrm{L}}$, respectively) of under-aged specimens. (a) No. 4, (b) No. C4.

向にあったが， $\delta_{\mathrm{L}}$ は $W / d=40 \sim 100$ （試験片 S3 S6）では実質 上ほとんどゼロである。破面 SEM 観察（Fig. 6）によれば, 粒界破壊と粒内破壊が混在し, 小サイズ（S3）ほど粒内破壊 の割合が増すとはいえ, 粒界破壊の発生を伴っていた。 $W / d=16 （ \mathrm{~S} 1)$ になると， $\delta_{\mathrm{L}}$ が $10 \%$ 以上を生じ，このときは 全面粒内破壊であった。つまり，W/d $>40$ において $\delta_{\mathrm{L}} \approx 0$ と なるのは粒界破壊の発生に因るもので，大サイズ試験片（S6） ほど低ひずみ変形下で容易に粒界破壊が誘起され，他方，小 サイズ試験片（S1）では粒界破壊が抑制された結果と理解さ れる。 $W / d<20$ のとき, 破壊様式が粒界破壊から粒内破壊へ 遷移する原因としては， $\sigma_{0.2}$ と同じく $W / d$ の減少が結晶粒間 拘束力の減少をむたらすことによると考えられる。一方, 合 金 No. C4 では, $\delta_{\mathrm{U}}$ は W/d の減少に依存せずほとんど一定值 を示し, $\delta_{\mathrm{L}}$ は $W / d$ の減少とともに単調に増加した。そして, 結晶粒径が微細であるため $W / d=70 \sim 400$ の広範囲にわたり, 破壊様式はつねに粒内破壊であった。すなわち, 微細結晶粒 であるため $W$ の変化に伴う結晶粒間拘束力の差異は $\delta_{\mathrm{U}}$ に影 響しないと言える。これは, 粒界と粒内における析出の不均 一が粗大粒合金に比べて大幅に緩和される上に，粒界へのす べり集中の度合も低いために粒界破壊に至らないものと考え られる。W/dの減少に伴う $\delta_{\mathrm{L}}$ の増大は, 平行部断面のアス ペクト比 $W / T$ (本試験片では $T=1 \mathrm{~mm}$ のため $W$ ) による一 般的な傾向と同一挙動である。時効条件の影響としては, 合 金 No. 4 の場合, PA 材の $\sigma_{0.2}$ と $\delta$ の試験片サイズ依存性は UA 材と類似していた。しかし, 最も小サイズの試験片 S1 に 
おいても粒界破壊が発生し， $\delta$ は UA 材の $1 / 2$ 以下に低下し た。これは, 粒界析出物の粗大化に伴う PFZ の成長により粒 界でのひずみ集中が容易になり, 粒界破壊が促進されるため と考えられる。一方，合金No. C4 ではPA 材であっても依然 として粒内破壊を呈し， $\delta$ の W/d 依存性むUA 材より小さな 変化にとどまった。

\section{6. 結言}

過剰 Si 6000 系アルミニウム合金の粗粒と微粒シート材に ついて，6種類のサイズの試験片を用いて 2 種類の時効条件 下で引張試験を行った。引張特性に及ぼす試験片サイズ効果 を FEM解析および破面形態観察と合せて考察した。得られ た結果は以下のとおりである。

（1）試験片サイズが小さいほよ゙, 耐力 $\left(\sigma_{0.2}\right)$ は低下し, 破断伸び（ $\delta$ ）は増大した。その変化は，粗粒合金において 顕著であった。

(2) 応力 -ひずみ構成関係を一定とする大变形 FEM 解析 を行い, 引張特性に及ぼす試験片の幾何学的形状の影響を検 討した結果, 試験片サイズ依存性はミクロ組織因子との相互 効果として理解すべきことがわかった。

（3）FEM解析より, 試験片 S2 の平行部（長さ $L$, 幅 $W$ ) において塑性变形が局所化する現象が認められた。よって, シート材の引張試験片を設計するときには，肩部の曲率半径 とともに $W / L$ のバランスを考慮すべきである。

（4）試験片サイズ効果のパラメータとして，W $W$ 結晶粒径 (d) の比 $W / d$ を用いて $\sigma_{0.2}$ と $\delta$ を統一的に整理することがで きた。
（5）粗粒合金の亜時効（UA）材の場合，W/d の減少とと もに破壊様式が粒界性から粒内性へ遷移し， $\delta$ は増大した。 これは，Wの減少により結晶粒間拘束力が小さくなることに 因ると考えられた。 $W / d>40$ 以上に $W$ が大きな試験片では粒 界破壊を生じ，局部伸び（ $\left.\delta_{\mathrm{L}}\right)$ をほとんど示さなかった。

（6）微粒合金 UA 材では，W/d=70 400 の広範囲でつねに 粒内破壊を生じた。W/d の減少とともに $\delta$ は増大したが，粗 粒合金ほど変化は大きくなかった。

（7）ピーク時効（PA）材は，UA 材に比べて $\sigma_{0.2}$ および $\delta$ の試験片サイズ依存性が大きく現れなかった。

\section{謝 辞}

本研究は, 日本アルミニウム協会 平成 14 15 年度「アル ミニゥム研究助成事業」によるものであり，ここに謝意を表 します。

\section{参 考 文 献}

1）里 達雄，松田健二：軽金属，53（2003），449-453.

2）谷村眞治, 辰見栄隆, 楳田 努, 北田明夫 : 日本機械学会論文 集 A, 68 (2002), 1762-1766.

3）横山 隆：日本機械学会 2001 年度年次大会講演論文集（I）, (2001)，355-356

4）臺丸谷政志，小林秀敏，津田 紘：材料， 53（2004）, 12401246.

5）木下勝之，上西 研，大㠃修平：日本機械学会材料力学部門 講演会講演論文集，（2002）, 559-560.

6）富田佳宏：塑性と加工，36（1995），2-9.

7）駒井謙治郎編：機械材料学，(社)日本材料学会，（2001）, 76.

8）西田正孝：応力集中，森北出版，(1984)，632-634.

9) S. Miyazaki, K. Shibata, H. Fujita: Acta Met., 27 (1979), 855-862. 